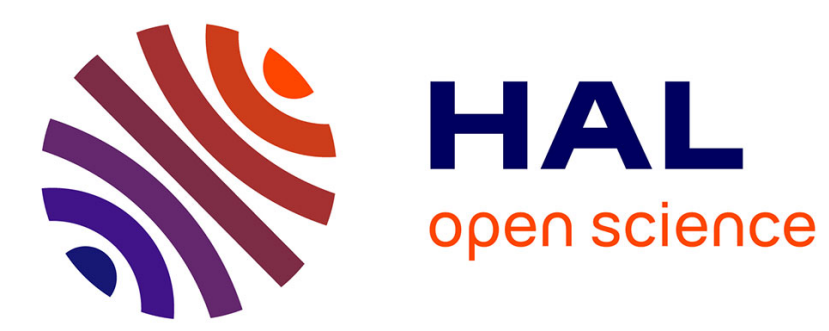

\title{
Mass Spectrometric Study of the Gas Phase During Chemical Vapor Deposition of Pyrolytic Carbon
}

\author{
F. Fau-Canillac, F. Carrere, A. Reynes, C. Vahlas, F. Maury
}

\section{To cite this version:}

F. Fau-Canillac, F. Carrere, A. Reynes, C. Vahlas, F. Maury. Mass Spectrometric Study of the Gas Phase During Chemical Vapor Deposition of Pyrolytic Carbon. Journal de Physique IV Proceedings, 1995, 05 (C5), pp.C5-89-C5-96. 10.1051/jphyscol:1995508 . jpa-00253764

\section{HAL Id: jpa-00253764 https://hal.science/jpa-00253764}

Submitted on 1 Jan 1995

HAL is a multi-disciplinary open access archive for the deposit and dissemination of scientific research documents, whether they are published or not. The documents may come from teaching and research institutions in France or abroad, or from public or private research centers.
L'archive ouverte pluridisciplinaire HAL, est destinée au dépôt et à la diffusion de documents scientifiques de niveau recherche, publiés ou non, émanant des établissements d'enseignement et de recherche français ou étrangers, des laboratoires publics ou privés. 


\title{
Mass Spectrometric Study of the Gas Phase During Chemical Vapor Deposition of Pyrolytic Carbon
}

\author{
F. Fau-Canillac, F. Carrere, A. Reynes, C. Vahlas and F. Maury \\ Laboratoire de Matériaux, URA 445, 118 Route de Narbonne, 31077 Toulouse, France
}

\begin{abstract}
The pyrolysis of $\mathrm{CH}_{4}$, of $\mathrm{C}_{3} \mathrm{H}_{8}$ and of the mixture $20 \mathrm{C}_{3} \mathrm{H}_{8} / 80 \mathrm{CH}_{4}$ was investigated in a hat wall CVD reactor by mass spectrometry. Experiments were conducted as a function of temperature and of surface-to-volume $(\mathrm{S} / \mathrm{V})$ ratio of the substrate. The main by-products of the pyrolysis were identified and reaction mechanisms were proposed taking into account homogenous decomposition/formation reactions. Cyclic species are possibly involved in the formation mechanism of pyrocarbon.
\end{abstract}

\section{INTRODUCTION}

The use of pyrocarbon, i.e. of carbon deposited by pyrolysis of gaseous hydrocarbons, as a matrix in thermostructural composites aims to obtain pronounced refractory character, mass gain relatively to other families of composites and high performance mechanical properties [1]. Improvement of the mechanical properties of the composites in general can also be achieved by depositing a thin film of pyrocarbon as interphase between the matrix and the reinforcement. In this way, aromatic layers more or less parallel to the surface of the reinforcement are obtained [2]. During mechanical stressing of the composites the weak Van der Waals interlayer bonds yield first and permit limited debonding and fiber pullout.

When pyrocarbon is used as a matrix material, the yield of the deposition relatively to by-products like coke and soot and the decrease of the infiltration time and temperature are the important features in the deposition process. When it is used as interphase material, the morphology of the deposit, i.e. the extend and the orientation of the aromatic layers relatively to the reinforcement is the important feature. All these variables are function of the operating conditions through the composition of the gas phase in the vicinity of the deposition area. The knowledge of this reactive gas phase allows for the comprehension of the reaction mechanisms and consequently, for the optimization of both processes: It is the link between the overall operating parameters, which are accessible by the experimentalist and the characteristics of the obtained films.

In that which follows, a mass spectrometric study of the gas phase during the CVD of pyrocarbon will be presented, by sequentially processing the pyrolysis of pure methane $\mathrm{CH}_{4}$, of propane $\mathrm{C}_{3} \mathrm{H}_{8}$, and of a mixture $80 \% \mathrm{CH}_{4}-20 \% \mathrm{C}_{3} \mathrm{H}_{8}$, as a function of temperature and of surface-to-volume (S/V) ratio of the substrate. The composition of the gas phase is identified in each case. Reaction mechanisms are proposed for the homogeneous and the heterogeneous decomposition of the reactants.

\section{EXPERIMENTAL}

Experiments were conducted in a standard horizontal, hot wall quartz reactor of $-200 \mathrm{~mm}$ isothermal zone in the investigated conditions. Working pressure and gas flows were regulated by Baratron-gaugemonitored throttle valve and by $\mathrm{PC}$-monitored mass flow meters respectively. Experiments were processed 
by using Prodair Instrument Quality $\mathrm{CH}_{4}$ and $\mathrm{C}_{3} \mathrm{H}_{8}$ and Prodair $5 \mathrm{~N}$ helium, $\mathrm{He}$, as a dilution gas. Deposition was performed on silicon nitride $\mathrm{Si}_{3} \mathrm{~N}_{4}$, polished flat substrates and on carbon fibers preforms.

Table 1: The investigated operating conditions for the decomposition chemistry of methane and/or of propanc

\begin{tabular}{ll}
\hline Temperature, $\mathrm{T}$ & $753-1293 \mathrm{~K}\left(480-1020^{\circ} \mathrm{C}\right)$ \\
Pressure, $\mathrm{P}$ & $1333-2066 \mathrm{~Pa}(10-15.5$ torr $)$ \\
$\mathrm{CH}_{4}$ flow & $72-90 \mathrm{sccm}$ \\
$\mathrm{C}_{3} \mathrm{H}_{8}$ flow & $0-18 \mathrm{sccm}$ \\
$\mathrm{He}$ flow & $0-72 \mathrm{sccm}$ \\
Total flow & $29-388 \mathrm{sccm}$ \\
$\mathrm{C}_{3} \mathrm{H}_{8}$ in the reacting gas phase & $0-20 \mathrm{at} \%$ \\
\hline
\end{tabular}

Heating of the reactor was performed under $30 \mathrm{sccm}$ of He. Sampling and analysis of the yases was initiated after an approximately $60 \mathrm{~min}$ stabilization period, corresponding to the regulation of flow in the mass spectrometer

A PC-monitored Balzers QMH 420 quadripole was connected to the reaction chamber through a micrometric valve and a $2 \mathrm{~mm}$ diameter quartz tube At $953 \mathrm{~K}\left(680^{\circ} \mathrm{C}\right)$, i.e. just below the decomposition temperature of $\mathrm{C}_{3} \mathrm{H}_{8}$ in the adopted operating conditions, no change of the relative intensities of the ionic fragments was observed when quartz tubes with different lengths were placed within the isothermal zone of the reactor. It was thus checked that the sampling disposal does not originate heterogeneous reactions which could mask homogeneous gas phase reactions. During the experiments sampling was realized at the middle of the isothermal zone of the reactor.

The mass spectra of $\mathrm{CH}_{4}$ and of $\mathrm{C}_{3} \mathrm{H}_{8}$ below their decomposition temperatures were initially recorded They are in agreement with literature information [3], and help to establish in each case the reference state for the comparison with the spectra originated from the reaction products. These baseline spectro correspond to the fragmentation of the molecules originated from the electron bombardment in the ionization chamber at the entrance of the quadripole. The decomposition rate of different ionic fragments is, in this way, calculated by using the relation

$$
T_{1}(\%)=\left(1-I_{x} / I_{0}\right) * 100
$$

where $I_{0}$ represents the intensity of an ionic fragment characteristic of a yaseous species before decomposition and $I_{x}$ represents the intensity of the same fragment at different stages of the decomposition process. The formation rate of an ionic fragment is calculated in a similar way, by using the relation:

$$
T_{\mathrm{f}}(\%)=\left(\mathrm{I}_{\mathrm{x}} / \mathrm{I}_{\max }\right) * 100
$$

where $I_{\max }$ is the maximum intensity of the ionic fragment, generally obtained in conditions of total decomposition of the initial species. Above the decomposition temperature of the reactants the variations of these rates are characteristic of the evolution of the gas phase with temperature.

The ionic fragments which were selected as representatives of the studied species are presented in Table 2. Since it was not possible in this study to differentiate acetylene from ethylene, fragment 26 was taken as representative of both $\mathrm{C}_{2} \mathrm{H}_{2} / \mathrm{C}_{2} \mathrm{H}_{4}$. The intensity of each selected ionic fragment was systematically corrected relatively to contributions which were attributed to other species.

It is worth noting that it is difficult to perform a rigorous quantification of the composition of the reactants by using this technique, because the response of a species in the quadripole depends not only on its ionization yield, but also on its diffusion coefficient in the gas phase

Because of the need to study the role of minor species in the gas phase chemistry during the pyrolysis, preliminary experiments were necessary for the determination of the imprecision of each measurement as a function of the relative intensity. From the obtained results it appears that variations of the intensities in the order of $10^{-13}$ or less are not significant, ie they do not allow for the unambiguous determination of the presence or not of the species in the spectrometer. 
Table 2: Ionic fragments. selected as representatives of the studied species.

\begin{tabular}{l|ccccccccc} 
Species & $\mathrm{H}_{2}$ & $\mathrm{CH}_{4}$ & $\mathrm{C}_{2} \mathrm{H}_{2} / \mathrm{C}_{2} \mathrm{H}_{4}$ & $\mathrm{C}_{2} \mathrm{H}_{6}$ & $\mathrm{C}_{3} \mathrm{H}_{4}$ & $\mathrm{C}_{3} \mathrm{H}_{6}$ & $\mathrm{C}_{3} \mathrm{H}_{8}$ & $\mathrm{C}_{4} \mathrm{H}_{6}$ \\
Ionic fragments & 2 & 16 & 26 & 30 & 19 & 41 & 43 & 54 \\
\hline Species & $\mathrm{C}_{4} \mathrm{H}_{8}$ & $\mathrm{C}_{4} \mathrm{H}_{31}$ & $\mathrm{C}_{6} \mathrm{H}_{6}$ & $\mathrm{C}_{6} \mathrm{H}_{10}$ & $\mathrm{C}_{6} \mathrm{H}_{14}$ & $\mathrm{C}_{7} \mathrm{H}_{8}$ & $\mathrm{C}_{7} \mathrm{H}_{14}$ & $\mathrm{C}_{8} \mathrm{H}_{10}$ \\
Ionic fragments & 56 & 58 & 78 & 67 & 71 & 91 & 83 & 106
\end{tabular}

\section{RESULTS AND DISCUSSION}

\subsection{Comparative study of the gas phase compositions during the pyrolysis of pure $\mathrm{CH}_{4}$, of $\mathrm{C}_{3} \mathrm{H}_{8}$ and} of a $20 \mathrm{C}_{3} \mathrm{H}_{8} / 80 \mathrm{CH}_{4}$ mixture.

It was first verified that pyrolysis of $\mathrm{CH}_{4}$ in typical chemical vapor infiltration (CVI) operating pressure, i.e $2066 \mathrm{~Pa}$ (15.5 torr), is initiated near $1273 \mathrm{~K}\left(1000^{\circ} \mathrm{C}\right)$, in agreement with previous reports ([4] and references therein) and that hydrogen $\mathrm{H}_{2}$, is the main gaseous by-product of the pyrolysis [5]. The same study was conducted for $\mathrm{C}_{3} \mathrm{H}_{8}$, (diluted in 80 at $\%$ He because of the elevated reactivity of pure $\mathrm{C}_{3} \mathrm{H}_{8}$ in the conditions of Table 1), with total gas flow $=90 \mathrm{sccm}$. As was previously shown ([6-8] and references therein), $\mathrm{H}_{2}, \mathrm{CH}_{4}, \mathrm{C}_{2} \mathrm{H}_{2} / \mathrm{C}_{2} \mathrm{H}_{4}$ and $\mathrm{C}_{3} \mathrm{H}_{6}$ are the main by-products of the pyrolysis of $\mathrm{C}_{3} \mathrm{H}_{8}$. These preliminary experiments illustrated the dominant reactions for the two processes, i.e. reaction (3) for $\mathrm{CH}_{4}$ $[5]$ and reactions (4) and (5) for $\mathrm{C}_{3} \mathrm{H}_{8}[7,9]$ :

$$
\begin{aligned}
& \mathrm{CH}_{4} \Leftrightarrow 2 \mathrm{H}_{2}+\mathrm{C} \\
& \mathrm{C}_{3} \mathrm{H}_{8} \Leftrightarrow \mathrm{CH}_{4}+\mathrm{C}_{2} \mathrm{H}_{4} \\
& \mathrm{C}_{3} \mathrm{H}_{8} \Leftrightarrow \mathrm{H}_{2}+\mathrm{C}_{3} \mathrm{H}_{6}
\end{aligned}
$$

In view of the higher energy of $\mathrm{C}-\mathrm{H}$ than $\mathrm{C}-\mathrm{C}$ bonds in the $\mathrm{C}_{3} \mathrm{H}_{8}$ molecule (422 versus $352 \mathrm{~kJ} / \mathrm{mol}$ ), reaction (4) seems predominant over reaction (5). However it is worth noting that in the overall reaction mechanism for the pyrolysis of $\mathrm{C}_{3} \mathrm{H}_{8}$, secondary reactions leading to heavier linear and cyclic hydrocarbons become progressively predominant[10]

In order to evidence the influence of $\mathrm{CH}_{4}$ on the decomposition mechanism of $\mathrm{C}_{3} \mathrm{H}_{8}$ a comparative study of the formation/decomposition rates of the ionic fragments was conducted, in the systems $\left(20 \mathrm{C}_{3} \mathrm{H}_{8} / 80 \mathrm{He}\right)$ and $\left(20 \mathrm{C}_{3} \mathrm{H}_{8} / 80 \mathrm{CH}_{4}\right)$ at $1293 \mathrm{~K}\left(1023{ }^{\circ} \mathrm{C}\right)$. At this temperature the major part of $\mathrm{CH}_{4}$ is still unaffected and, consequently, its contribution to the decomposition of $\mathrm{C}_{3} \mathrm{H}_{8}$ can be checked. Although $\mathrm{CH}_{3}{ }^{\prime}$ and $\mathrm{H}^{\prime}$ radicals can also participate in the reactions, the evolution of $\mathbf{H}^{\prime}$ was not considered since it can be originated from the decomposition of both $\mathrm{CH}_{4}$ and $\mathrm{C}_{3} \mathrm{H}_{8}$

The intensities of the ionic fragments characteristics of butadiene $\mathrm{C}_{4} \mathrm{H}_{6}$, butene $\mathrm{C}_{4} \mathrm{H}_{8}$, butane $\mathrm{C}_{4} \mathrm{H}_{10}$, cyclohexene $\mathrm{C}_{6} \mathrm{H}_{10}$, and xylene $\mathrm{C}_{8} \mathrm{H}_{10}$ are identical in both systems, indicating that $\mathrm{CH}_{4}$ does not participate in the formation/decomposition reactions of these species. On the other hand the intensities of ionic fragments characteristics of $\mathrm{H}_{2}$, ethane $\mathrm{C}_{2} \mathrm{H}_{6}$, propylene $\mathrm{C}_{3} \mathrm{H}_{6}$, benzene $\mathrm{C}_{6} \mathrm{H}_{6}$ and toluene, $\mathrm{C}_{7} \mathrm{H}_{8}$ increase when $\mathrm{He}$ is substituted by $\mathrm{CH}_{4}$ while the intensity of the ionic fragment corresponding to acetylene/ethylene, $\mathrm{C}_{2} \mathrm{H}_{2} / \mathrm{C}_{2} \mathrm{H}_{4}$ decreases. These variations are presented in Table 3 and they are further illustrated in Figure 1 for the case of $\mathrm{C}_{2} \mathrm{H}_{6}$ by varying the percentage of $\mathrm{CH}_{4}$ in the reactive gas phase.

$\mathrm{C}_{2} \mathrm{H}_{6}$ is formed following reaction (6) $[3,4,11,12]$ and (7) [4]:

$$
\begin{aligned}
& 2 \mathrm{CH}_{3}{ }^{\prime} \Leftrightarrow \mathrm{C}_{2} \mathrm{H}_{6} \\
& 2 \mathrm{CH}_{4} \Leftrightarrow \mathrm{C}_{2} \mathrm{H}_{6}+\mathrm{H}_{2}
\end{aligned}
$$

The production of $\mathrm{C}_{3} \mathrm{H}_{6}$ after reaction (5) and the excess of $\mathrm{CH}_{4}$ seem to favor the left-to-right direction of reaction (8) reported in [4]

$$
\mathrm{C}_{3} \mathrm{H}_{6}+\mathrm{CH}_{4} \Leftrightarrow \mathrm{C}_{2} \mathrm{H}_{6}+\mathrm{C}_{2} \mathrm{H}_{4}
$$


However, the increase of $\mathrm{C}_{2} \mathrm{H}_{6}$ as evidenced in Figure 1 and the decrease of $\mathrm{C}_{2} \mathrm{H}_{4}$ (which can also be explained by the right-to-left direction of reaction (4) in the presence of $\mathrm{CH}_{4}$ ), indicate that the opposite direction is preferred.

Table 3: Relative intensity of ionic fragments $2,26,30,41,78$ and 91 resulting from the pyrolysis of $\left(20 \mathrm{C}_{3} \mathrm{H}_{8} / 80 \mathrm{He}\right)$ and $\left(80 \mathrm{C}_{3} \mathrm{H}_{8} / 20 \mathrm{CH}_{4}\right)$ mixtures and comparative variation (\%). $\mathrm{T}=1293 \mathrm{~K}\left(1020^{\circ} \mathrm{C}\right), \mathrm{P}=2066 \mathrm{~Pa}(15.5$ torr $)$.

\begin{tabular}{|c|c|c|c|}
\hline \multirow[b]{2}{*}{ Ionic fragment } & \multicolumn{2}{|c|}{ Relative intensity } & \multirow{2}{*}{$\begin{array}{l}\text { Variation } \\
\Delta \mathrm{x} / \mathrm{x}(\%)\end{array}$} \\
\hline & $\mathrm{C}_{3} \mathrm{H}_{8} / \mathrm{He}$ & $\mathrm{C}_{3} \mathrm{H}_{8} / \mathrm{CH}_{4}$ & \\
\hline $2\left(\mathrm{H}_{2}\right)$ & $2,7.10-8 \pm 0,2.10-8$ & $3,7,10-8 \pm 0,2.10-8$ & +37 \\
\hline $26\left(\mathrm{C}_{2} \mathrm{H}_{2} / \mathrm{C}_{2} \mathrm{H}_{4}\right)$ & $2,4 \cdot 10-8 \pm 0,2 \cdot 10-8$ & $1,6 \cdot 10-8 \pm 0,2 \cdot 10-8$ & -65 \\
\hline $30\left(\mathrm{C}_{2} \mathrm{H}_{6}\right)$ & $5,4 \cdot 10-11 \pm 0,5 \cdot 10-11$ & $1,3 \cdot 10-10 \pm 0,2 \cdot 10-10$ & +76 \\
\hline $41\left(\mathrm{C}_{3} \mathrm{H}_{6}\right)$ & $2,9 \cdot 10-10 \pm 0,2 \cdot 10-10$ & $5,6.10-10 \pm 0,6 \cdot 10-10$ & +93 \\
\hline $78\left(\mathrm{C}_{6} \mathrm{H}_{6}\right)$ & $3,5.10-9 \pm 0,2 \cdot 10-9$ & $4,2.10-9 \pm 0,4 \cdot 10-9$ & +20 \\
\hline $91\left(\mathrm{C}_{7} \mathrm{H}_{8}\right)$ & $2,0.10-10 \pm 0,1 \cdot 10-10$ & $3,3.10-10 \pm 0,2 \cdot 10-10$ & +65 \\
\hline
\end{tabular}

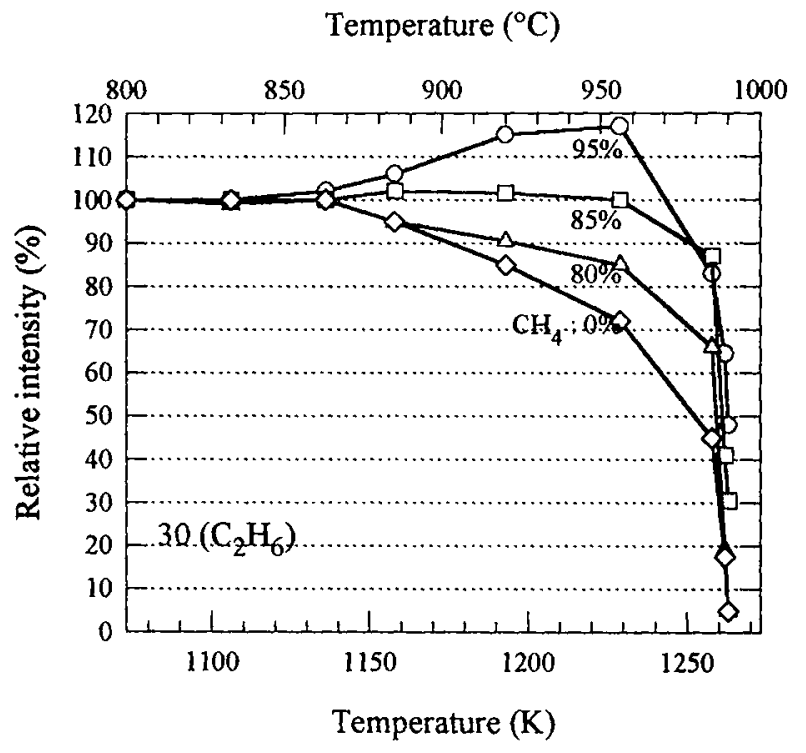

Figure 1: Variation of the decomposition rate of the ionic fragment 30 , characteristic of $\mathrm{C}_{2} \mathrm{H}_{6}$ as a function of temperature for different compositions of a $\mathrm{C}_{3} \mathrm{H}_{8} / \mathrm{CH}_{4}$ reactive gas phase. $\mathrm{P}=2066 \mathrm{~Pa}$ (15.5 torr).

\subsection{Influence of temperature on the gas phase composition}

The influence of temperature on the composition of the gas phase was evidenced on the $\left(20 \mathrm{C}_{3} \mathrm{H}_{8} / 80 \mathrm{CH}_{4}\right)$ mixture at $\mathbf{P}=2066 \mathrm{~Pa}$ (15.5 torr), by studying the evolution of the relative intensities of fragment 43 corresponding to $\mathrm{C}_{3} \mathrm{H}_{8}$, of the fragments $2,16,26$ and 41 corresponding to the major linear species, of the fragments 54 and 56 corresponding to heavy linear hydrocarbons and of the fragments $67,78,91$ and 106 corresponding to cyclic hydrocarbons.

$\mathrm{C}_{3} \mathrm{H}_{8}$ is stable at low temperatures. It starts decreasing at $953 \mathrm{~K}\left(680{ }^{\circ} \mathrm{C}\right)$ and it attains $0 \%$ at approximately $1180 \mathrm{~K}\left(910^{\circ} \mathrm{C}\right)$, corresponding to its total decomposition.

The major species of the reactive gas phase are $\mathrm{H}_{2}, \mathrm{CH}_{4}, \mathrm{C}_{2} \mathrm{H}_{2} / \mathrm{C}_{2} \mathrm{H}_{4}$ and $\mathrm{C}_{3} \mathrm{H}_{6}$, in agreement with the results on the decomposition of $\mathrm{C}_{3} \mathrm{H}_{8}$. Their evolution with temperature is presented in Figure $2 . \mathrm{C}_{6} \mathrm{H}_{6}$, whose behavior will be discussed later, is also considered as a major species above $1173 \mathrm{~K}\left(900^{\circ} \mathrm{C}\right)$. 
The increase of $\mathrm{H}_{2}$ above $953 \mathrm{~K}\left(680^{\circ} \mathrm{C}\right)$ is principally due to the decomposition of $\mathrm{C}_{3} \mathrm{H}_{8}$. The moderate increase at this temperature of $\mathrm{CH}_{4}$ can be attributed to the decomposition of other hydrocarbons following the principle of reaction (4) and/or to recombinations like the one of reaction (9) [13]:

$$
\mathrm{C}_{2} \mathrm{H}_{6}+\mathrm{C}_{3} \mathrm{H}_{6} \Leftrightarrow \mathrm{CH}_{4}+2 \mathrm{C}_{2} \mathrm{H}_{4}
$$

The decrease of $\mathrm{CH}_{4}$ above $1223 \mathrm{~K}\left(950^{\circ} \mathrm{C}\right.$ ) is probably due to its direct decomposition. The comparison of this temperature with the temperature of $1273 \mathrm{~K}\left(1000^{\circ} \mathrm{C}\right)$ at which the decomposition of pure $\mathrm{CH}_{4}$ is initiated, illustrates the influence of $\mathrm{C}_{3} \mathrm{H}_{8}$ on the decomposition of $\mathrm{CH}_{4} . \mathrm{C}_{2} \mathrm{H}_{2} / \mathrm{C}_{2} \mathrm{H}_{4}$ are absent below $993 \mathrm{~K}$ $\left(720^{\circ} \mathrm{C}\right)$. Above this temperature they rapidly increase and they are roughly stabilized above $1213 \mathrm{~K}(940$ ${ }^{\circ} \mathrm{C}$ ). These species are essentially originated from the direct decomposition of $\mathrm{C}_{3} \mathrm{H}_{8}$.

The evolution of the so called heavy linear hydrocarbons $\mathrm{C}_{4} \mathrm{H}_{6}$ and of $\mathrm{C}_{4} \mathrm{H}_{8}$, is presented in Figure 3 . The formation of $\mathrm{C}_{4} \mathrm{H}_{6}$ above $988 \mathrm{~K}\left(715^{\circ} \mathrm{C}\right)$ is related to the formation of $\mathrm{C}_{4} \mathrm{H}_{8} . \mathrm{C}_{4} \mathrm{H}_{8}$ is formed above $953 \mathrm{~K}\left(680^{\circ} \mathrm{C}\right)$, which is the starting temperature for the decomposition of $\mathrm{C}_{3} \mathrm{H}_{8}$ following reactions (10) [14], or (11) [11,14]:

$$
\begin{aligned}
& 2 \mathrm{C}_{3} \mathrm{H}_{8} \Leftrightarrow 2 \mathrm{CH}_{4}+\mathrm{C}_{4} \mathrm{H}_{8} \\
& \mathrm{C}_{3} \mathrm{H}_{8} \rightarrow \mathrm{CH}_{3}{ }^{\circ}+\mathrm{C}_{3} \mathrm{H}_{5}{ }^{\prime} \Leftrightarrow \mathrm{C}_{4} \mathrm{H}_{8}
\end{aligned}
$$

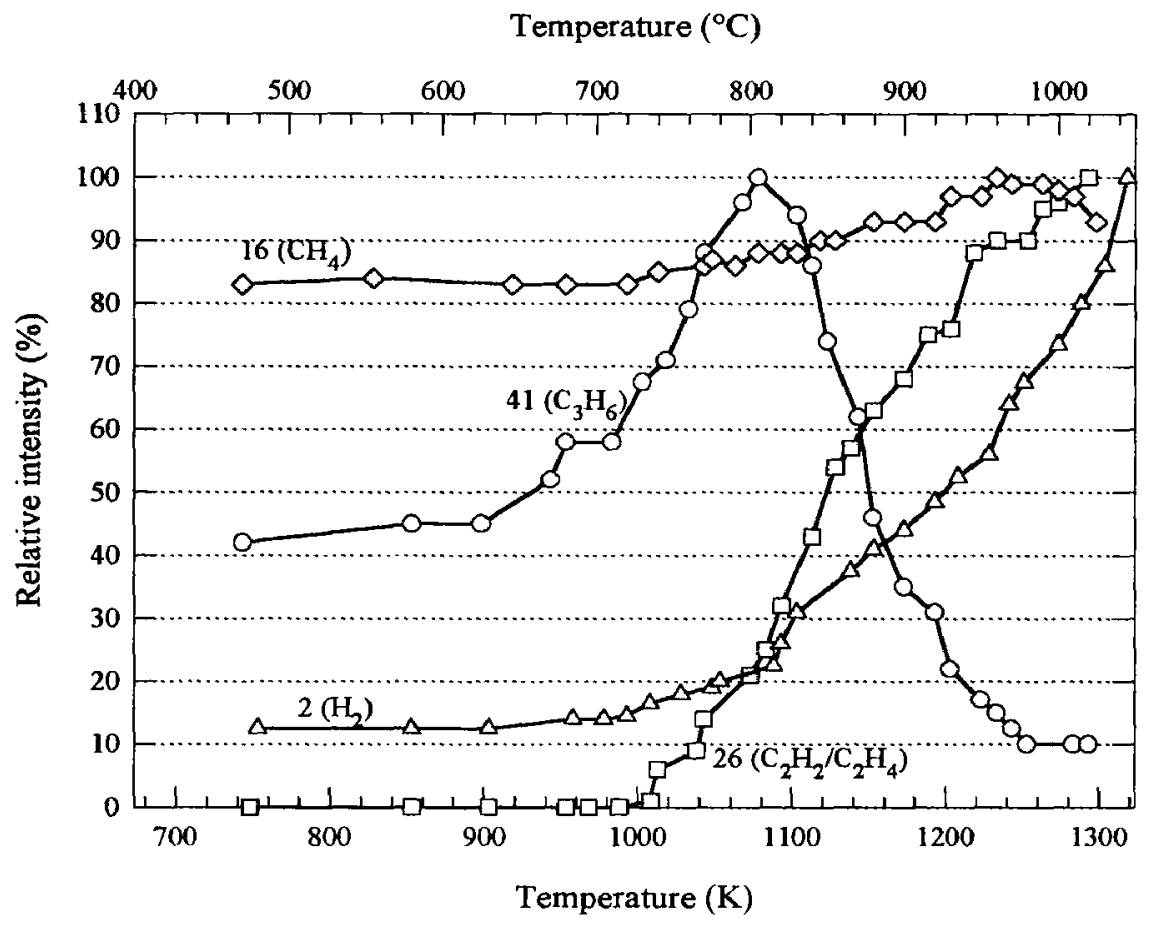

Figure 2: Pyrolysis of a mixture $20 \mathrm{C}_{3} \mathrm{H}_{8} / 80 \mathrm{CH}_{4}$. Variation of the formation and of the decomposition rates of ionic fragments corresponding to species $\mathrm{H}_{2}, \mathrm{CH}_{4}, \mathrm{C}_{2} \mathrm{H}_{2} / \mathrm{C}_{2} \mathrm{H}_{4}$ and $\mathrm{C}_{3} \mathrm{H}_{6}$ as a function of temperature.

$\mathrm{C}_{4} \mathrm{H}_{6}$ is formed from the direct decomposition of $\mathrm{C}_{4} \mathrm{H}_{8}$ [15]. In addition to this on line process, other recombination reactions (direct or among radicals) have been proposed for the formation/decomposition of these species [15]. These reactions can explain the decrease of the intensity of fragment 56 at $1083 \mathrm{~K}(810$ 
${ }^{\circ} \mathrm{C}$ ) corresponding to the direct decomposition of $\mathrm{C}_{4} \mathrm{H}_{8}$, the decrease of the intensity of fragment 54 at $1183 \mathrm{~K}\left(910^{\circ} \mathrm{C}\right)$ corresponding to the formation of $\mathrm{C}_{\mathrm{x}} \mathrm{H}_{3}{ }^{\prime}$ radicals with $1 \leq x \leq 3$, or the further increase of fragment 56 above $1243 \mathrm{~K}\left(970^{\circ} \mathrm{C}\right)$.

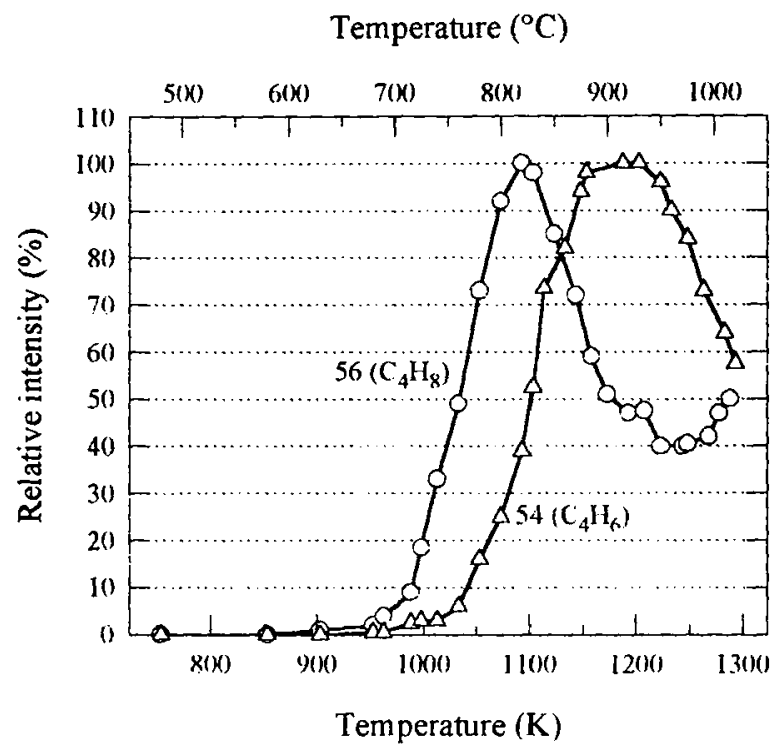

Figure 3: Pyrolysis of a mixture $20 \mathrm{C}_{3} \mathrm{H}_{k} / 80 \mathrm{CH}_{4}$. Variation of the formation and of the decomposition rates of ionic fragments corresponding to species $\mathrm{C}_{4} \mathrm{H}_{5}$ and $\mathrm{C}_{2} \mathrm{H}_{8}$ as a function of temperature.

The evolution of the cyclic hydrocarbons with temperature is presented in Figure 4 . The general mechanism for the formation of cyclic species is initiated with $\mathrm{C}_{4} \mathrm{H}_{6} . \mathrm{C}_{4} \mathrm{H}_{6}$ reacts with $\mathrm{C}_{2} \mathrm{H}_{4}$ to form $\mathrm{C}_{6} \mathrm{H}_{10}$ $[8,16]$ and finally $\mathrm{C}_{6} \mathrm{H}_{6}$. Indeed, $\mathrm{C}_{6} \mathrm{H}_{1 !}$ strongly increases above $993 \mathrm{~K}\left(720^{\circ} \mathrm{C}\right)$, which is also the formation temperature of $\mathrm{C}_{4} \mathrm{H}_{6}$ and of $\mathrm{C}_{2} \mathrm{H}_{4} \cdot \mathrm{C}_{4} \mathrm{H}_{6}$ also reacts with $\mathrm{C}_{3} \mathrm{H}_{6}$ to finally form $\mathrm{C}_{7} \mathrm{H}_{3}[15,16]$ and possibly with $\mathrm{C}_{4} \mathrm{H}_{8}$ to form $\mathrm{C}_{8} \mathrm{H}_{10}$

\subsection{Influence of the surface/volume ( $S / V)$ ratio on the gas phase composition}

The influence of the surface/volume $(\mathrm{S} / \mathrm{V}$ ) ratio of the reactor on the composition of the gas phase was performed on the $\left(20 \mathrm{C}_{3} \mathrm{H}_{8} / 80 \mathrm{CH}_{4}\right)$ mixture at $\mathrm{T}=1293 \mathrm{~K}\left(1020{ }^{\circ} \mathrm{C}\right.$ ) and $\mathrm{P}=2066 \mathrm{~Pa}(15.5$ torr). Experiments were conducted successively without substrate and with an increasing number of preforms. $\mathrm{S} / \mathrm{V}$ was in this way varied between 0.9 and $35 \mathrm{~cm}^{-1}$. It appears that when $\mathrm{S} / \mathrm{V}$ increases the intensities of the fragments which are characteristics of the linear hydrocarbons remain unchanged. On the contrary, as shown in Figure 5 , the intensities corresponding to the aromatic species $\mathrm{C}_{6} \mathrm{H}_{6}, \mathrm{C}_{7} \mathrm{H}_{8}$ and $\mathrm{C}_{8} \mathrm{H}_{10}$ decrease and that of $\mathrm{H}_{2}$ increases. This behavior indicates that homogeneous and heterogeneous reactions coexist during the pyrolysis of hydrocarbons. It also seems to confirm that in the investigated conditions it is the aromatic hydrocarbons which participate in the heterogeneous reactions while the other species are mainly implied in the homogeneous reactions. It thus appears that the aromatic hydrocarbons are decomposed by a dehydrogenation process probably leading to the formation of pyrocarbon. 


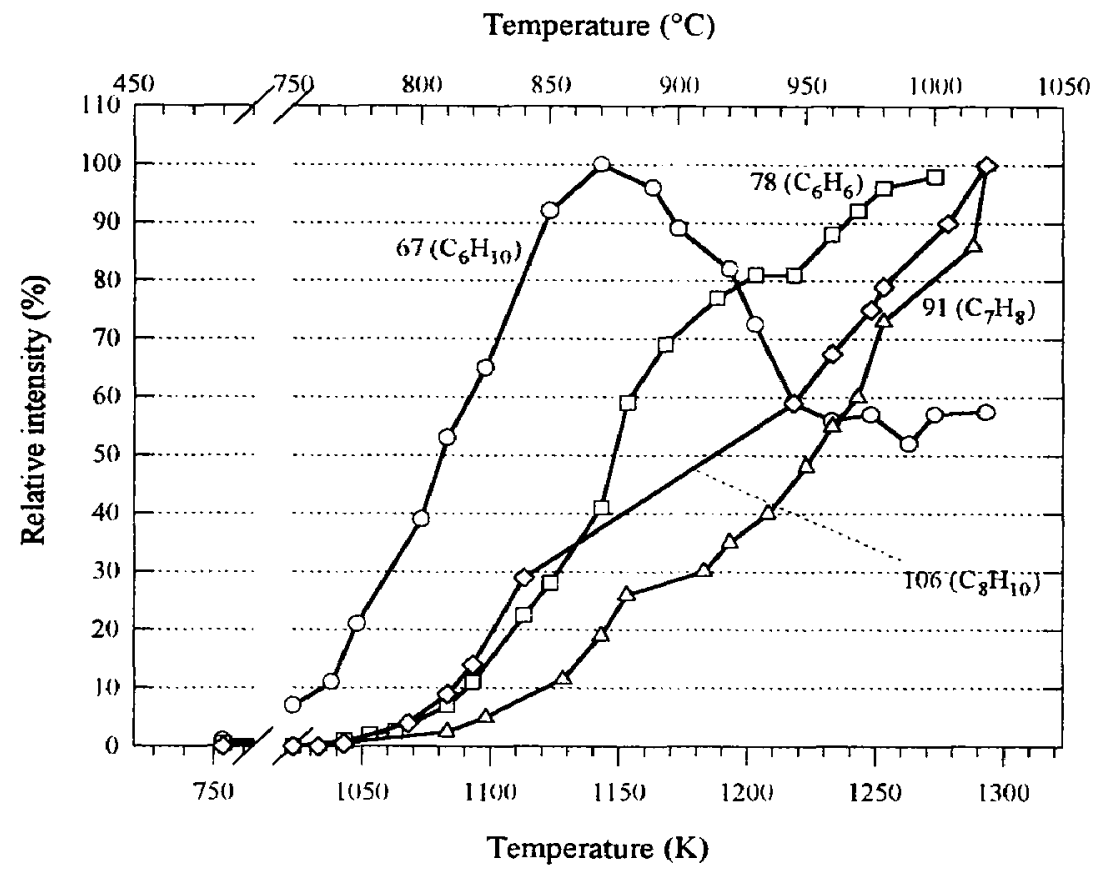

Figure 4: Pyrolysis of a mixture $20 \mathrm{C}_{3} \mathrm{H}_{8} / 80 \mathrm{CH}_{4}$. Variation of the formation and of the decomposition rates of ionic fragments corresponding to species $\mathrm{C}_{6} \mathrm{H}_{10} . \mathrm{C}_{6} \mathrm{H}_{5} . \mathrm{C}_{-} \mathrm{H}_{8}$ and $\mathrm{C}_{8} \mathrm{H}_{1,}$ as a function of temperature

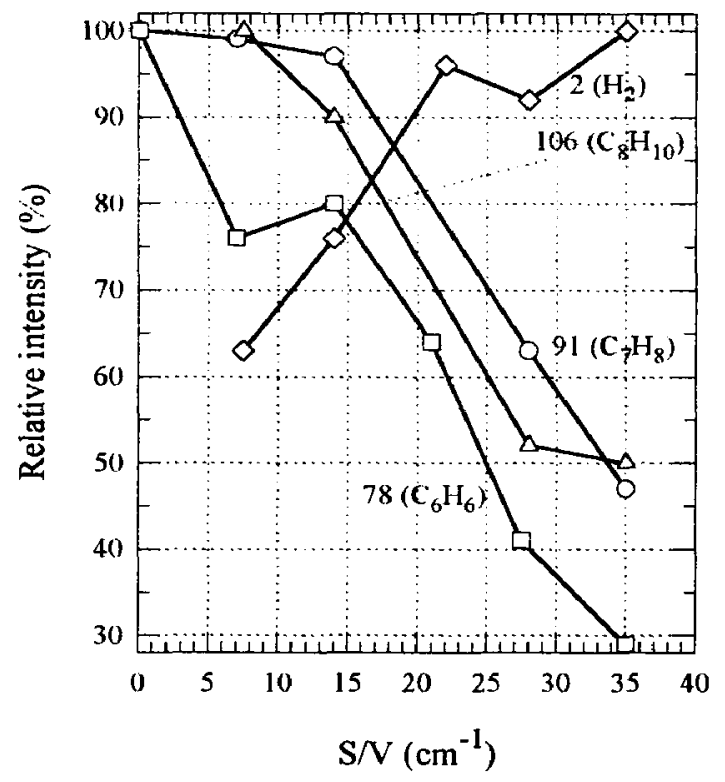

Figure 5: Pyrolysis of a mixture $20 \mathrm{C}_{3} \mathrm{H}_{\mathrm{k}} / 80 \mathrm{CH}_{4}$. Variation of the formation and of the decomposition rates of ionic fragments corresponding to species $\mathrm{H}_{2} . \mathrm{C}_{8} \mathrm{H}_{16} \mathrm{C}_{6}, \mathrm{H}_{6}$ and $\mathrm{C}-\mathrm{H}_{8}$ as a function of the surface-to-volume ratio of the substrate. 


\section{CONCLUSIONS}

The pyrolysis of $\mathrm{CH}_{4}$, of $\mathrm{C}_{3} \mathrm{H}_{8}$ and of the mixture $20 \mathrm{C}_{3} \mathrm{H}_{8} / 80 \mathrm{CH}_{4}$ was investigated in a hot wall CVD reactor by mass spectrometry. Experiments were conducted as a function of operating temperature and of surface-to-volume $(\mathrm{S} / \mathrm{V})$ ratio of the substrate. The main by-products of the pyrolysis of the mixture were identified as being: $\mathrm{H}_{2}, \mathrm{CH}_{4}, \mathrm{C}_{2} \mathrm{H}_{2} / \mathrm{C}_{2} \mathrm{H}_{4}, \mathrm{C}_{3} \mathrm{H}_{6}, \mathrm{C}_{2} \mathrm{H}_{6}, \mathrm{C}_{4} \mathrm{H}_{6}, \mathrm{C}_{4} \mathrm{H}_{8}, \mathrm{C}_{6} \mathrm{H}_{6}$, cyclohexene $\mathrm{C}_{6} \mathrm{H}_{10}$, toluene $\mathrm{C}_{7} \mathrm{H}_{8}$ and dimethylbenzene $\mathrm{C}_{8} \mathrm{H}_{10}$. Based on the obtained results, reaction mechanisms were proposed taking into account homogenous decomposition/formation reactions. The variation of the $\mathrm{S} / \mathrm{V}$ ratio helped to distinguish between heterogeneous and homogeneous reactions, evidenced the implication of the cyclic species in the heterogeneous reactions and showed that their decomposition is due to a dehydrogenation process, probably leading to the formation of pyrocarbon.

The correlation of these results with the characteristics of the obtained films, i.e. their growth rate and or their morphology, is expected to establish the link between the overall operating parameters, which are accessible by the experimentalist and the aimed properties of the pyrocarbon.

\section{Acknowledgments}

The authors wish to thank A.Castillo for technical assistance and B.Delperier and J.P.Richard of the Societe Europeene de Propulsion (SEP) for support.

\section{References}

1. Choury J.J, "SEP carbon and ceramic composites in aeronautics and space applications ", Proceedings, The First International Symposium on Functionally Gradient Materials, Sendai 1990, Yamanouchi M., Koizumi M., Hirai T., Shiota I. Eds. pp. 157-167.

2. Despres J.F, Vahlas C. and Oberlin A. « Chemical vapor deposition of pyrolytic carbon on polished substrates », EUROCVD 9th, Tampere 1993, Mäntylä T. Ed. Journal de Physique, v.3, colloque C3, 1993. pp. 563-570

3. Comu A and Massot R Compilation of mass spectral data (Presse Universitaire de France, Paris, 1966).

4. Billaud F., Baronnet F, Freund E, Busson C. and Weill J., Rev.Inst.Fr.Petrole 44(6) (1989) 813-823.

5 Thery S., Libert P., Marchand A and Thebault J., J.Chimie Physique 81(11/12) (1984) 819-825.

6. Volkan A.G. and April G.C., Ind. Fng.Chem., Process Des. Dev. 16(4) (1977) 429-436.

7. Kolke T. and Gardiner W.C.J., J.Phys.Chem. 84 (1980) 2005-2009.

8. McConnell C.F. and Head B.D. Pyrolysis: Theory and Industrial Practice (Academic Press, 1991) pp. $25-45$

9. Allendorf M D and Kee R J., J.Electrochem. Soc. 138(3) (1991) 841-852.

10. Illés V. Acta Chim.Acad. Scient. Hungaricae 67(1) (1971) 41-60.

11. Burcat A. Fuel 54 (1975) 87-93.

12 Hidaka Y., Nakamura T., Tanaka H., Inami K. and Kawano H., Int.J.Chem.Kinetics 22 (1990) 701709

15. Billaud F., Baronnet F and Niclause M., J.Chim.Physique 77(2) (1980) 357-360

14. Jezequel J. Y. Baronnet F. and Niclause M., J.Chim.Physique 80(5) (1983) 455-467.

15 Kem RD. Singh H.J and Wu C.H. Int.J.Chem. Kinetics 20 (1988) 731-747.

16 Nohara D and Sakai T, Ind.Eng.Chem.Res. 31 (1992) 14-19. 